\title{
Attitudes to predictive DNA testing in familial adenomatous polyposis
}

\author{
S Whitelaw, J M Northover, S V Hodgson
}

\begin{abstract}
Attitudes to predictive DNA testing for familial adenomatous polyposis were documented in 62 affected adults. Patient views on prenatal testing and termination of pregnancy for this disorder were sought, as were opinions on the most suitable age to offer predictive testing for at risk children and the most appropriate age to begin screening. While $15(24 \%)$ of those questioned stated that they would proceed to termination of pregnancy if a prenatal test indicated that the unborn baby was affected, in clinical practice no one has yet requested this option. Six $(10 \%)$ people who had refrained from having children for fear of passing on the polyposis gene felt that the arrival of prenatal testing would enable them to consider planning a family. The majority of patients $(93 \%)$ said they would like their children tested by DNA analysis at birth or in infancy, but felt that 10 to 12 years was the most appropriate time to discuss the diagnosis with the child. ( $\mathcal{H}$ Med Genet 1996;33:540-543)
\end{abstract}

Key words: predictive DNA testing; attitude; familial adenomatous polyposis.

Familial adenomatous polyposis (FAP) is an autosomal dominant disorder characterised by the development of multiple premalignant adenomatous polyps in the colon and elsewhere in the gastrointestinal tract. Left untreated, the vast majority of patients will develop colorectal cancer, and patients are advised to undergo prophylactic colectomy soon after the polyps appear, usually in mid to late teens. FAP also predisposes the person to other potentially life threatening illnesses. For example, adenomas also occur in the duodenum, ${ }^{1}$ and malignancy at this site is now the most common cause of death in some series. ${ }^{2}$ Abdominal desmoid tumours, rare in the general population, occur in between 4 to $13 \%$ of FAP patients, and may reach a large size, developing in the small bowel mesentery, abdominal wall, or retroperitoneum. ${ }^{3}$ Complete removal of these tumours is often not possible and they may cause death by obstructing the ureters or bowel, infiltrating organs, and causing intraluminal haemorrhage. Brain tumours and thyroid cancer are a reported association with FAP, and there is an increased incidence of hepatoblastoma documented in the children of FAP patients. ${ }^{4}$

Like many other autosomal dominant disorders, however, the clinical course of this ill- ness is highly variable both within and between affected families. Some patients may experience several of the extracolonic complications mentioned above, while in others the effect of the disorder on their everyday lives may be minimal. While premature death in FAP is not inevitable, a recent life table analysis showed that FAP patients have a three fold relative risk of dying early compared to age and sex matched controls in the general population, even when screened and kept under close medical surveillance. ${ }^{5}$

Before the late 1980 s, at risk subjects were screened for rectosigmoid adenomas from the age of 10 to 16 years by regular sigmoidoscopy. Recently, it has been discovered that approximately $80 \%$ of affected people have a characteristic retinal pigmentation (CHRPE), and in some families this also can serve as a useful diagnostic marker. ${ }^{6}$ The cloning of the gene responsible for FAP on chromosome $5 \mathrm{q} 21,{ }^{7}$ designated the APC gene, now means that in a high percentage of cases presymptomatic and even prenatal diagnosis can be offered using either linkage or mutational analysis. ${ }^{89}$ Two important questions can now be addressed. What do people with FAP think is the best age to offer predictive DNA testing for FAP in their at risk children? How acceptable is prenatal testing and selective termination of pregnancy for FAP for couples at risk of having affected children?

The answers to these questions will undoubtedly be influenced by psychological factors, perception of disease severity, and philosophical, personal, and religious attitudes to predictive DNA testing and termination of pregnancy. In turn, the perception of the severity of the disease and its subjective effects are likely to be strongly affected by the person's previous experience of FAP. In haemophilia, it has been shown that a woman's perception of the pros and cons of prenatal diagnosis is strongly influenced by personal experience of the course of the disease in closest male relatives. $^{10}$

This study was initiated before predictive DNA testing for FAP was readily available and was still a relatively new concept. Its purpose was to assess patient attitude to predictive testing and potential demand for this service in clinical practice before it was widely available.

\section{Patients and methods}

We studied 62 patients ( 33 male, 29 female) with FAP who attend the outpatient department of St Mark's Hospital, London. Sixtythree people were approached when attending
Received 15 December 1995 Revised version accepted for publication 1 March 1996 
Table 1 A summary of features in relation to patient attitude to prenatal testing and termination of pregnancy

\begin{tabular}{llll}
\hline & $\begin{array}{l}\text { Those who said they } \\
\text { would opt for selective } \\
\text { termination of pregnancy }\end{array}$ & $\begin{array}{l}\text { Those who would not } \\
\text { consider termination } \\
\text { of pregnancy }\end{array}$ & Undecided \\
\hline Number & 15 & 39 & 8 \\
$\begin{array}{l}\text { Age of patients } \\
\text { <30 years }\end{array}$ & $2(13 \%)$ & $23(59 \%)$ & $5(63 \%)$ \\
$\quad \begin{array}{l}\text { 30-50 years } \\
\text { >50 years }\end{array}$ & $5(33 \%)$ & $10(26 \%)$ & $3(38 \%)$ \\
No who had children & $9(53 \%)$ & $6(15 \%)$ & \\
No who had one affected child & $4(26 \%)$ & $2(51 \%)$ & \\
$\begin{array}{l}\text { No who had more than one } \\
\text { affected child }\end{array}$ & $2(13 \%)$ & $2(5 \%)$ & \\
$\begin{array}{l}\text { No who had an extracolonic } \\
\text { complication themselves }\end{array}$ & $2(13 \%)$ & $1(2 \cdot 6 \%)$ & \\
$\begin{array}{l}\text { No who had FAP related death } \\
\text { in family }\end{array}$ & $10(67 \%)$ & $13(33 \%)$ & $1(12 \cdot 5 \%)$ \\
\hline
\end{tabular}

a routine OPD appointment, before receiving professional genetic counselling, and 62 agreed to participate. Median age of the patients was 38 years (range 19-67 years). Each patient had undergone prophylactic colectomy; 55 patients had an ileorectal anastomosis, four patients had a restorative proctocolectomy with ileoanal pouch formation, and three patients had a panproctocolectomy with formation of a permanent end ileostomy. Twenty-nine patients had children, of whom 10 had children in whom FAP had been diagnosed. The remainder had children whose disease status was still uncertain.

\section{ATTITUDE TO PREDICTIVE TESTING}

The following questions were used in a semistructured interview by the same interviewer.

If you knew it was possible to diagnose FAP in the early weeks of pregnancy, would you ask your doctor if you could have the prenatal test, and if so, why?

If the test showed that the unborn baby was affected by polyposis would you proceed to termination of pregnancy, and if so, why?

If it was possible to diagnose polyposis in early childhood by performing a blood test, would you want your own children tested at: (A) Birth. (B) Infancy. (C) 10-14 years. (D) Never. (E) Don't know?

At what age do you think children should be introduced to the concept of polyposis?

\section{STATISTICAL ANALYSIS}

This was performed using the $\chi^{2}$ test with Yates's correction.

\section{Results}

ATTITUDES TO PRENATAL TESTING

Forty patients $(64 \cdot 5 \%)$ stated that they would request prenatal testing if it was possible to diagnose polyposis in the early weeks of pregnancy; of these, 15 (24\%) (seven men, eight women) stated that they would proceed to termination of pregnancy if the fetus was affected.

Of the 15 patients who said they would opt for prenatal testing and termination of pregnancy if the unborn baby was diagnosed as likely to be affected, two (13\%) were under 30 years. Of the 39 who would not consider
Table 2 Patient opinion on most suitable age to inform children about polyposis

\begin{tabular}{lc}
\hline Age of child $(y)$ & No of patients \\
\hline Under 10 & 3 \\
10 & 20 \\
11 & 2 \\
12 & 6 \\
$10-12$ & 7 \\
$13-14$ & 13 \\
Over 14 & 1 \\
\hline
\end{tabular}

termination, $23(59 \%)$ were under 30 years $(\mathrm{p}<0 \cdot 01)$.

Six of the $15(40 \%)$ of the patients who said they would opt for termination had affected children compared to $4 / 39(10 \%)$ who would not $(\mathrm{p}<0 \cdot 01)$.

Ten of the 15 patients (66\%) who would opt for termination had at least one FAP related death in the family compared to $13 / 39(33 \%)$ who did not $(\mathrm{p}<0.05)$. These results are summarised in table 1 .

Reasons volunteered for opting for prenatal testing and termination were as follows. Six patients who had previously refrained from having children for fear of passing on the polyposis gene felt that the option of prenatal testing would enable them to consider planning a family, which they would otherwise not have done.

Six patients who had affected children stated that they felt very guilty about passing on the polyposis gene, and felt that had the prenatal option been available a great deal of unnecessary suffering might have been prevented.

Three patients who had children of unknown disease status said that they were very worried about the possibility of passing on the faulty gene, and felt that prenatal testing could have removed this chronic source of worry from their lives.

\section{ATTITUDE TO AGE AT WHICH PREDICTIVE} TESTING SHOULD BE PERFORMED IN THEIR CHILDREN

A total of $58 / 62$ stated that they would like their children tested at birth, $1 / 62$ at 10 years, and $3 / 62$ at puberty.

PATIENT OPINION ON THE MOST SUITABLE AGE TO INTRODUCE THE SUBJECT OF POLYPOSIS TO THEIR CHILDREN

A total of 51/62 patients discussed this issue. The results are summarised in table 2 .

\section{Discussion}

People with FAP may wish to know the results of their children's predictive tests, in order to spare those found to be at low risk unnecessary screening procedures and to relieve personal guilt and uncertainty. Adults at risk of developing FAP are clearly concerned about their own risk of developing cancer, and this may explain the high uptake of DNA testing in this group, which at St Mark's Hospital approaches $100 \%$. By comparison, the uptake of predictive testing in Huntington's disease (HD) may be less than $20 \%$, this difference being because 
people consider FAP treatable, whereas there is currently no treatment for HD. ${ }^{11} 12$

With regard to prenatal testing, although 40 patients $(64 \%)$ in this study stated that they would make use of prenatal testing if it was available, only $15(24 \%)$ said that they would consider termination of pregnancy if the unborn baby was affected. This finding is similar to a previous report of a cohort of people with FAP, where $15 / 25(60 \%)$ affected subjects said they would consider prenatal testing, but only four $(16 \%)$ would consider the termination option. ${ }^{13}$ People who were over 30 years, who already had an affected child or had a history of FAP related death in the family, were more likely to state that they would opt for prenatal testing and termination, and it is possible that these patients perceived FAP differently as a result of the emotional distress they associated with the disorder. In practice, none of affected subjects attending the St Mark's Polyposis Clinic in the last four years has requested prenatal testing, although only $2 / 62$ interviewed have yet to be in a position to request this service. A marked discrepancy between statement of intent and actual uptake in clinical practice has been observed in Huntington's disease, and it is possible that this also may occur in FAP. ${ }^{14}$ Factors influencing patient opinion may change over a period of time. Most patients under 30 years in this study do not know yet whether their children are affected, and more complete ascertainment of at risk subjects by polyposis registries should reduce death from colorectal cancer. The prenatal option may be taken up by the small group of patients who had previously refrained from having children for fear of passing on the gene.

There was a widespread feeling among the interviewees that children should not be told about polyposis until they were "old enough to understand". Most parents considered between 10 and 12 years to be the most appropriate age to introduce the subject, as they did not feel it was fair to "spring" the diagnosis at the often emotionally turbulent time of puberty. However, it is interesting that $58 / 62(93 \%)$ wished to test their children at birth and withhold this information from them for a decade.

The predictive testing of children for adult onset disorders is a complex issue. Present consensus is that it cannot be justified ethically or morally for disorders such as Huntington's disease where symptoms are rare in childhood and there is no treatment. ${ }^{15}$ In the case of FAP, however, diagnosis before 18 years is frequently necessary to prevent the onset of colorectal cancer, and screening in most centres already begins before the legal age of consent. It is thus logical to test them at least by the time clinical screening would be instigated. This was agreed by the working party on the genetic testing of children of the Clinical Genetics Society. ${ }^{16}$

A majority of parents (58/62) stated that they would request testing of their children at birth/ infancy if it was available, and this finding was consistent with a previous report from Germany, where most parents wanted testing performed before the age of 10 years. ${ }^{17}$ Reasons given included (1) removing ambiguity about the disease status of their children, which some parents felt was a chronic source of stress, and (2) satisfying parental curiosity. Medical management before puberty, however, is unlikely to be altered by the information predictive testing provides, and it is difficult therefore to envisage any clear advantage for the child. Furthermore, early testing may distort parentchild or sib-sib relationships, damage the child's self esteem, remove the child's right to decide about testing at a later age, and generate unwarranted anxiety about unrelated symptoms. Who is to judge what is in the best interests of the child in this situation, and what limits, if any, should be placed on parental autonomy?

Although the Working Party's conclusions were that it is unwise to offer predictive testing for adult onset genetic conditions in childhood, but that in early onset diseases, and where medical and surgical intervention was likely to be instigated once the diagnosis was made (as in FAP), this guideline could not be adhered to, there was no general indication about when children should be tested in these conditions. Only 28 out of 49 geneticists (and 214 out of 260 paediatricians) responded positively to a questionnaire item asking whether they would test a 5 year old whose parents wanted to know his/her genetic status for FAP (compared with two geneticists and 100 paediatricians when asked the same question about $\mathrm{HD}$, and 40 geneticists and 223 paediatricians regarding hyperlipidaemia).

One might conclude from this that the appropriate stance to take in the case of FAP was that testing a child at birth was not indicated, and that in general such tests should be deferred until the age at which endoscopic surveillance was to start (about 10 years) unless clinical symptoms suggest early onset of FAP polyps which can occasionally occur before 10 years. However, there are as yet no data to support any view regarding the optimum age to perform predictive testing.

In conclusion, 62 patients with FAP have been asked their views on DNA testing. The majority of patients stated that they would not consider prenatal testing and termination of pregnancy under any circumstances, but a significant minority $(25 \%)$ felt that they would take up such testing. In practice, no-one, however, has yet taken up this option.

Most parents stated that they would like their children to have DNA testing at birth or in infancy, and the majority felt that the concept of FAP should be discussed with their children before puberty. Careful long term assessment and documentation of the impact of predictive testing will be needed in FAP, as in the rapidly increasing number of other single gene disorders for which DNA testing is available.

We would like to acknowledge the staff of the St Mark's Polyposis Registry for their help with this study.

1 Domizio P, Talbot IC, Spigelman AD, Williams CB, Phillips RK. Upper gastrointestinal pathology in familial adenomatous polyposis: results from a prospective study of 102 patients. F Clin Pathol 1990;43:738-43.

2 Bussey $\mathrm{H}$, Eyers A, Ritchie S, Thomson J. The rectum in adenomatous polyposis: the St Mark's policy. $\mathrm{Br} F$ Surg 1985;72:S29-31. 
3 Northover JM, Murday V. Familial colorectal cancer and familial adenomatous polyposis. Baillieres Clin Gastrenterol 1989;3:593-613

4 Bulow S. Incidence of associated diseases in familial polyposis coli. Semin Surg Oncol 1987;3:84-7.

5 Nugent K, Spigelman A, Philips R. Life table analysis of death from all causes in familial adenomatous polyposis (FAP) treated by colectomy and ileorectal anastomosis. Leeds Castle Polyposis Group 5th Biennial Meeting, Copenhagen, Denmark, 1993.

6 Polkinghorne PJ, Ritchie S, Neale K, Schoeppner G, Thomson JP, Jay BS. Pigmented lesions of the retinal pigment epithelium and familial adenomatous polyposis. Eye 1990; 4:216-21.

7 Groden J, Thliveris A, Samowitz W, et al. Identification and characterization of the familial adenomatous polyposis coli gene. Cell 1991;66:589-600.

8 Eckert WA, Jung C, Wolff G. Presymptomatic diagnosis in families with adenomatous polyposis using highly polymorphic dinucleotide CA repeat markers flanking the APC gene. $\mathcal{F}$ Med Genet 1994;31:442-7.

9 Cottrell S, Bicknell D, Kaklamanis L, Bodmer WF. Molecular analysis of APC mutations in familial adenomatous polyposis and sporadic colon carcinomas. Lancet 1992; 340:626-30.
10 Beeson D, Globus M. Prenatal testing in hemophilia. $\mathrm{Am}$ 7 Med Genet 1984;20:107-14.

11 Adam S, Wiggins S, Whyte P, et al. Five year study of prenatal testing for Huntington's disease: demand, attitudes, and psychological assessment. $\mathcal{F}$ Med Genet 1993;30:549-56.

12 Tibben A, Niermeijer M, Roos R, et al. Understanding the low uptake of presymptomatic DNA testing for Huntington's disease. Lancet 1992;340:1416.

13 Burn J, Chapman P, Delhanty J, et al. The UK Northern Region Region genetic register for familial adenomatous polyposis coli: use of age of onset, congenital hypertrophy of the retinal pigment epithelium, and DNA markers in risk calculations. F Med Genet 1991;28:289-96.

14 Meissen G, Berchek R. Intended use of predictive testing by those at risk of Huntington's disease. Am $\mathcal{f}$ Med Genet 1987;26:283-93.

15 Bloch M, Hayden M. Opinion. Predictive testing for Huntington's disease in childhood: challenges and implications. Am ₹ Hum Genet 1990;46:1-4.

16 Report of a Working Party of the Clinical Genetics Society. The genetic testing of children. 7 Med Genet 1994;31: 785-97.

17 Friedl W, Caspari R, Piechaczek B, Propping P. Predictive DNA testing in familial adenomatous polyposis. Lancet 1991;337:1172. 